\title{
GCGR-related hyperglucagonemia
}

INSERM

\section{Source}

INSERM. (1999). Orphanet: an online rare disease and orphan drug data base. GCGRrelated hyperg/ucagonemia. ORPHA:438274

A rare tumor of pancreas caused by mutations in the GCGR gene characterized by pancreatic alpha cell hyperplasia, pancreatic neuroendocrine tumors and markedly increased serum glucagon levels in the absence of a glucagonoma syndrome. Clinical manifestations may include abdominal pain, pancreatitis, fatigue, diarrhea, and diabetes mellitus. 